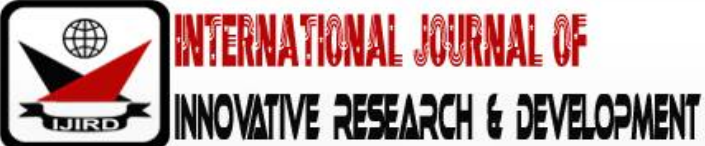

ISSN 2278 - 0211 (Online)

\section{Talent Management and Entrepreneurial Sustainability in Organizations}

\author{
Dr. Obialor, Donatus Chukwemeka \\ Lecturer, Department of Business Management, University of Uyo, Uyo, Nigeria
}

\begin{abstract}
:
Given the current dynamic business environment, organizations need to adapt quickly to maintain competitive advantage and grow sustainably. The study investigated the effect of talent management on entrepreneurial sustainability of Inn son Motors Limited. T-test Statistic was used in testing the hypotheses based on data sourced from 20 employees. The findings revealed that talent attraction and development have significant effect on organizational profit and given product development. The study concludes that for an organization to balance its economic health, social equity and environmental resilience and remain competitive, talent management become sacrosanct.
\end{abstract}

Keywords: Talent management, entrepreneurial sustainability, talent attraction

\section{Introduction}

The management of human capital which drives the organization towards performance is increasingly coming under scrutiny in such a context. Thus, talent management activities occupy a significant amount of organizational resources (Madan and Bhatnagar 2018). Due to the dynamic nature of the business environment, organizations have to recognize that identifying, developing and retaining of talents is imperative for organizational success. There was an era when people needed companies “organizational power' but today's current realities, organizations now need people.

Similarly, there was a time when machines, capital, brand image, and even geographical locations were regarded as a source of competitive advantage, but today the reverse is the case as talented employees are now source of competitive edge for organizations. Talent management is a set of integrated organizational human resource processes designed to attract, develop, motivate and retain productive, and engaged employees.

The goal of talent management is to create a high-performance, sustainable organization that meets its strategic and operational goals and objectives. It is normally a competency-based approach to managing human capital in an organization. It includes integrated systems, strategy alignment with business goals, and measuring success in terms of business outcomes and more recently; a focus on evidence-based talent decision-making using talent measurements and analytics (Madan and Bhatnagar 2018). Talent management goes beyond traditional people management, focusing on the skills and competencies people bring to an organization. The primary goals of talent management are to ensure that the organization has the skills it needs where it needs them and when it needs them to execute its business strategy.

Organizations know that they must have the best talent in order to succeed in the hyper-competitive and increasingly complex global economy. Along with the understanding of the need to hire, develop, and train talented people, organizations are in era where the environment and the society are being threatened by the activities of business. More importantly is the natural resources depletion and environmental degradation, including desertification, drought, land degradation, freshwater scarcity and air, water and land pollution all add to the list of challenges humanity faces. Overcoming the above challenges calls for talent management (TM)' practice. Through talent management, an organization would be able to attract, retain, and manage a workforce that will help in minimizing the negative impact business activities has on the environment.

Madan and Bhatnagar (2018) defined entrepreneurial sustainability as the discovery, creation and exploitation of entrepreneurial opportunities that contribute to sustainability by generating social and environmental gains for others in society.

There are three dimensions of the entrepreneurial activity, the social, economic and environmental. The social dimension is directed towards achieving social change and making resources available to a larger audience. Although cases of social entrepreneurship entail the creation of value that embraces both social and economic aspect, the focus is on social value, while economic value creation is seen as absolutely essential in order to ensure financial viability. This can be materialized within a social action context and in terms of providing catalytic leadership in areas of social concern with the purpose of change.

The economic prosperity dimension promotes a reasonable quality of life through the productive capacity of organizations and individuals in society (Dean and McMullen 2007). Economic prosperity involves the creation and distribution of goods and services that will help to raise the living standard around the world. With respect to the 
environmental dimension, while industry is considered one of the largest contributors to environmental degradation, it also has the potential to minimize its negative impact. Over the past years, a plethora of such management initiatives have developed. According to Dean and McMullen (2007), opportunities for environmental entrepreneurs exist as to the discovery and implementation of new, more environmentally friendly, product or process technologies.

\subsection{Statement of the Problem}

The human existence is at risk due to global warming caused by operations of business activities. The air, water, and land are polluted, and the usage of natural resources without replacing them, is at high rate thereby putting the lives of future generation in danger. In current times, the call for environmental sustainability through the use of renewable energy sources, waste recycling management, green technologies that will reduce air emission is yet to be incorporated by firms' especially those operating in Nigeria. Among the likely reasons that could cause firms' not to think in this new and challenging direction might be not having the right people with the right but proficient skills. Thus, the need for talent management becomes imperative in sustaining the entrepreneurial spirit in an organization.

\subsection{Objective of the Study}

The main objective of the study is to examine the extent of the relationship between talent management (TM) and entrepreneurial sustainability (ES). Specifically, the study is to:

- Investigate how talent attraction affects entrepreneurial sustainability of an organization

- Examine the effect of talent development on entrepreneurial sustainability.

- Assess the effect of talent attraction on green product development of an organization.

- Ascertain the relationship between talent development and profit of an organization.

\subsection{Research Questions}

The following research questions are raised;

- To what extent does talent attraction affect entrepreneurial sustainability?

- To what extent does talent development affect entrepreneurial sustainability?

- To what extent does talent attraction affect green product development?

- To what extent does talent development affect profit of an organization?

\subsection{Research Hypotheses}

The following hypotheses were formulated for the study:

- $\mathrm{Ho}_{1}$ : There is no significant effect between talent attraction and entrepreneurial sustainability.

- $\mathrm{Ho}_{2}$ : Talent development has no significant effect on entrepreneurial sustainability.

- $\mathrm{Ho}_{3}$ : Talent attraction has no significant effect on green product development.

- $\mathrm{Ho}_{4}$ : Talent development has no significant effect on profit of an organization.

\subsection{Scope of the Study}

The researcher concentrated on Innoson Motors Limited Nnewi, the commercial city of Anambra state, Nigeria. This is the geographical scope. The researcher examined the link between talent attraction and talent development on profit generation and green product development. This is the content scope.

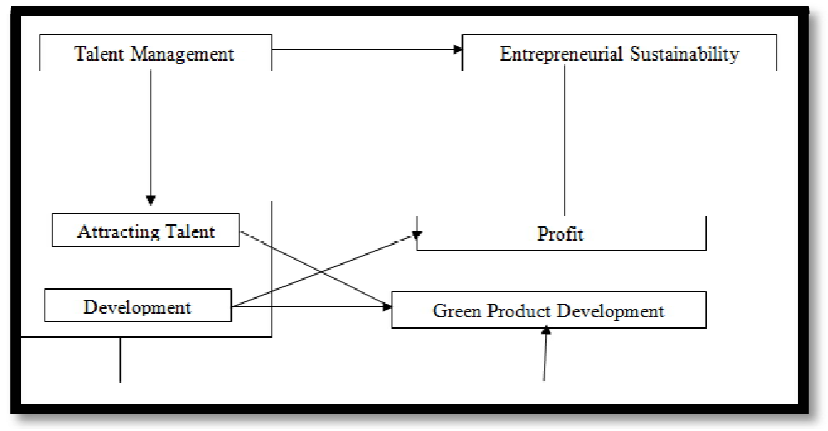

Figure 1: Review of Related Literature

\subsection{The Concept of Talent Management (TM)}

Talent is a person's ability and aptitude to deliver on commitments. Glen (2007) states that talent is the product of ability (competence, education, training and experience), coupled with employees' retention (engagement, development, challenge and wellness) and satisfaction. Talent management can be seen as organizational activities aimed at attracting, selecting, developing and retaining the best employees with the most strategic roles (roles necessary to achieve organizational strategic priorities). In the view of Keoye (2014), talent management refers to the anticipation of required human capital for an organization and the planning to meet those needs. Similarly, Bethke-Langenegger, Mahler and Staffelbach (2011) sees talent management (TM), as a gathering of activities that aims to (explicitly) support corporate strategy as a strategic tool for achieving and enhancing organizational success and for surviving in the current competitive global market (Harris, Craig \& Light 2011). 
From another perspective, Al-Ariss, Cascio and Paauwe (2014) argue that talent management is activities and processes that involves the following: (1) systematic identification of positions that differentially contribute to an organization's sustainable competitive advantage; (2) the development of a diverse talent pool to fill these roles, and the development of a differentiated human resource architecture to facilitate filling them; (3) continued commitment to the organization and to the well-being of societies, while taking local and national contexts into account. The study used the following dimensions as identified by Mariann and Kristin (2014) in measuring talent management:

- Talent Attraction: Attracting talent is the step concerned with creation of company awareness and acquiring the right individual to join the company, and how to effectively incorporate the new talented workers in the firm. At this stage the study stresses three important considerations, namely; Reputation Management, Employer Branding and Workforce Planning). These aspects will attach to the significance of identifying what is to be considered a talent for the specific company in compliance with key positions.

To be able to attract the right talent to key positions, attention towards reputation management and employer branding becomes vital. The business should try to make talents realize that working in this specific company, will be the best choice they'll ever make. Employer branding can have a strategic effect in "future-proofing' the firm reputation. To attract the best, the company has to act like the best, where "Firms with strong positive reputations attract better people.' (Mariann and Kristin, 2014).

Furthermore, Mariann and Kristin (2014) find it vital to focus on planning the workforce in the attempt to attract key individuals. Reputation is clearly a driver for attraction both internally and externally; yet, in order to effectively manage to attract talents possessing the specific competencies required, the study suggest workforce planning to be essential. Workforce planning is a future forecast of the needed employee skill, which takes into account diverse business scenarios (Harris, Craig and Light, 2011) cited in (Madan and Bhatnagar, 2018). For leaders to be able to diagnose problems and to best leverage the workforce, the development of system for workforce planning becomes helpful to achieve the workforce's contribution to value creation as desired (Longenecker and Fink, 2013) cited in (Madan and Bhatnagar 2018). The follow quote emphasizes this: "having the right number of people at the right place at the right time with the right skill sets and levels of motivation are fundamental to talent management' (Tarique and Schuler 2010) cited in (Mariann and Kristin, 2014).

- $\quad$ Talent Development: The second dimension used in this study in measuring talent management is development. Development is found to be favourable if the company is focused on needs and expectations of talents. Mariann and Kristin (2014) argue that organizational learning development and trainings, strategies, and knowledge creation and sharing are significant actions for increased development of a talented individual. In general organizations that have invested in talent development expects a return in terms of increased motivation and job satisfaction, stronger trust, and commitment to leaders.

Additionally, this will positively affect the organizational outcome for the company, such as company attractiveness (i.e. enhanced reputation and employer branding), achievement of the firms objectives and aspirations, customer satisfaction, and importantly, corporate profit (financial outcome) (Bethke-Langenegger, Mahler and Staffelbach 2011) cited in (Mariann and Kristin, 2014). By focusing on actively pursuing the succession planning, this will contribute to develop the workforce to be prepared for filling desirable positions. Concentrating on development activities such as implementing development and training strategies, workforce segmentation and to make sure that the company possesses the talents required, both now and in the future, this will ensure that the firm meet its strategic objectives (Tarique and Schuler 2010, Garavan, Carberry and Rock, 2012) cited in (Mariann and Kristin, 2014). Talent development activities are typically undertaken by organizations to ensure that there are zero talent outages, to ensure planned succession rather than replacement, and to enhance the organizations reputation as a talent magnet (Garavan, Carberry and Rock 2012) cited in (Madan and Bhatnagar, 2018).

Garavan, Carberry and Rock 2012) cited in Mariann and Kristin, (2014) present four approaches when defining the content of talent development, where the focus has shifted towards a more inclusive approach, where development is not only targeted for "A players' but also "B players'. This form of inclusive approach is defined as a type of talent segmentation but where the entire group of employees are acknowledged, and regarded as making a contribution to the firm. By avoiding a merely focus on "A-players', and rather combine employees with different background, experience or even culture, can result in effective knowledge creation and sharing, hence adding value to the company. The subsequent quote simply underlines this logic: "To realize value creation, firms must accumulate, combine, and exploit resources' ((Mariann and Kristin, 2014).

Mariann and Kristin (2014) further states that talents should be developed more generally, where targeting competencies that will fit several roles, and reflecting organizational values is essential. In accordance with the above mentioned, the TM-Model stresses among other things, finding the key employee to key position, selecting based on determined criteria for competence (defined based on the talent definition), organizational learning, knowledge creating and job rotations (Collings 2014 cited in Mariann and Kristin, 2014).

\subsection{The Concepts of Entrepreneurial Sustainability}

Entrepreneurial primary objectives are to satisfy an unfulfilled need or to improve the way this need is currently being satisfied. This promising and fundamental goal must ensure that societal and environmental impact is not compromised. Economic and technological progress at any price, without considering societal development and environmental impact, is unsustainable and no longer feasible. Due to stringent measures put forth by government of various economics, new and existing ventures are increasingly aware of the need to adopts sustainable practices, both within their organization and as a result of their interaction with the societal and physical environment. 
According to Eroglu and Picak (2011), entrepreneurship is the practice of starting new organizations or revitalizing nature organizations, particularly new businesses generally in response to identified opportunities. However, McMullen, Sanchez, and Stout (2011) suggest that combinations of innovative, proactive and risk-taking behavior can create value in organizations.

Pacheco, Dean, and Payne (2010) defined entrepreneurial sustainability as the "discovery, creation, evaluation, and exploitation of opportunities to create future goods and services consistent with the sustainable development goals'. Research on entrepreneurial sustainability has combined two different entrepreneurship branches: social and environmental entrepreneurship. Dean and McMullen (2007) offer a comparison between the broader concepts of sustainable entrepreneurship to environmental entrepreneurship comparing it to social entrepreneurship. They explain that the latter tends to address mission-driven, rather than profit-driven entrepreneurships while entrepreneurial sustainability addresses environmental problems without neglecting profit. Organizations that respond to social and environmental problem by applying market mechanisms are referred to as hybrid organizations (Ebrahim, Battilana, and Mair, 2014). Entrepreneurial sustainability can further be referred to as the discovery, creation, and exploitation of entrepreneurial opportunities that contribute to sustainability by generating social and environmental gains for others in society (Hockerts and Wustenhagen, 2010; and Shepherd and Patzelt, 2011). In this perception, sustainable entrepreneurship real aim is not to produce long lasting products or services but rather, to create a certain positive impact.

Sustainable entrepreneurship lays "in between for-profit and not-for-profit, in between cash and cause. The main goal of the business activity of the sustainable entrepreneurs should be 'looking for prosperity' (Iyigun, 2015). Both sustainability and entrepreneurship require innovation, which, applied to both fields, imply a creative new combination of existing resources (Nicholls-Nixon, Cooper, and Woo 2000). Sustainable entrepreneurship strives to create value that is beneficial for society through opportunity creation, and development in an uncertain environment. This implies risktaking abilities, innovative attitude and alertness together with determined ethical concerns (Nicholls -Nixon et' al., 2000). This study studied two of the three dimensions of entrepreneurial sustainability which are economic prosperity (profit) and environmental sustainability (green product development). By green product, we mean products that are energy efficient, durable, and often having low maintenance requirement.

\subsection{Talent Management (TM) and Entrepreneurial Sustainability (ES)}

The call by environmentalists for firms to produce products that are environmentally friendly and the need to preserve the natural resources can be attained through talent management. Meaning that organization must attract, develop, and retain innovative workforce that can help them respond to market, social and environment needs. This can be achieved through attracting talent, developing talents, and retaining talents. Attracting talent is all about employing innovative people that will add value to the organization. Through on and off the job training, necessary skills need to bring novelty into organization for competitive sustainability to be achieved. With such skills acquired, ways on how to produce products that are healthy minimize land, water and air pollution without negating profit can also be achieved.

\section{Theoretical Review}

The term talent management gained prominence owing to an often-cited article by Mckinsey consultants which focused on the emerging "War for Talent' (Micheals, Handfield-Jones, and Axelrod, 2001). This is based on the assumption that talented high-performing individuals are rare and hence worth fighting for. Similarly, the resource-based-view (RBV) of firms holds that organizations can derive competitive advantage from resources that are valuable, rare, inimitable, and non-substitutable (Barney, 1991). But, Snell, Youndt, and Wright (1996) argue that "if the types and levels of skills are not equally distributed, such that some firms can acquire the talent they need and others cannot, then (ceteris paribus) that form of human capital can be a source of sustained competitive advantage'. Thus, the base of talent management is in Resource Base View (RBV). Further, talent management also draw on Human Capital Theory, which states that individuals and society derive economic benefits from investments in people (Sweetland, 1996).

Similarly, Taylor studied management subject as a scientific research in what is described in literature as the theory of scientific management (Taylor cited in Keoye, 2014). In his study, he found out that enterprises cannot satisfactorily benefit from workers and believed that forming and programming of doing works should be re-regulated by a scientific analysis and more output would be gained if they were standardized. According to Keoye (2014), Taylor observed that work order and environment existing in enterprises may give big damages at a degree that can reach to losses at an extent effecting national economy. He has also observed that some radical decisions must be taken in order to turn these factors causing inefficiency and effecting production negatively into neutral or to minimize them and he formed the principles of Scientific Management accordingly. Alugbuo (2004) summarized Taylor's principles of scientific management as follow: (i) The development of a true science of management so that the best method of performing each task could be determined; (ii) The scientific selection of workers so that each worker could be given responsibility for the task for which he /she was best suited; (iii) The scientific education of the workers; and (iv) Intimate friendly corporation between management and labour. The study builds the proposition by Taylor cited in Keoye, (2014) that people whose mental and physical skills are sufficient for works being standardized must be chosen, that is to say, the most suitable staff/ member must be chosen.

\subsection{Empirical Review}

The following supported this study; In the study of Jokar (2012) on Analysis of the relationship between talent management and performance evaluation of elite employees using data envelopment analysis technique in National 
Iranian Oil Products Distribution Company, research findings confirms the existence of a relationship between talent management and performance evaluation. Barabadi (2011) also investigated the relationship between talent management and organizational commitment in Social Security Organization of Golestan Province, the test results of Pearson's correlation coefficient showed that there is a direct and significant relationship between talent management and organizational commitment in Social Security Organization of Golestan Province.

Similarly, Abdi (2011) investigated the impact of talent management on production process in Iran Khodro Company, the results of research showed that there is a significant relationship between talent management and indicators of product process in Iran Khodro Company (production unit of Samand and Roa) and causes the improvement of production process. The study of Sharma and Behatengar, (2009), quoted by Amini (2012) and cited in Sani and Hassan (2016) on talent management-competent development, a key for leading world, concluded that Talent management helps in attracting the best talents to the related organization and reduces erosion of talented forces.

\section{Methodology}

This research is evaluative in nature. It evaluates relationship between talent management and entrepreneurial sustainability. The following steps have been undertaken to make this research objective and more accurate. The study used the survey research by adopting the non- probability sampling design and used the instrument of questionnaire for data collection. The population for the study comprised of 35 employees working in Innoson Motors Nnewi Anambra state. Due to the small size of the population, a sample of 20 employees were chosen to participate in the study based on their designation and experience. This 20 were drawn from departments of production, operations, marketing, human resource, finance and the top managers. The data sources consist of primary and secondary sources, validity of the questionnaire was done by presenting it to the experts for corrections and inputs (face validity) and also were strictly based on the research question (content validity). The reliability test was conducted by way of carrying out a pilot study and subjecting the outcomes of the pilot study to Cronbach Alpha statistic. T-test was used in analyzing data with the aid of SPSS version 20. All constructs in the questionnaire were measured with Likert scale ranging from 5 (strongly agree) to 1 (strongly disagree).

\section{Results from the Administered Questionnaires}

- Does your enterprise involve in any form of talent management?

\begin{tabular}{|c|c|c|}
\hline Option & No. of responses & Percentage (\%) \\
\hline Yes & 20 & 100 \\
\hline No & - & - \\
\hline Total & 20 & 100 \\
\hline
\end{tabular}

Table 1: Opinion on Whether Respondents Are Involved in Talent Management Source: Field Survey (2020)

Please indicate if necessary, all types of talent management practice in your organization.

\begin{tabular}{|c|c|}
\hline Dimensions of Talent Management & Response \\
\hline Talent Attraction & $100 \%$ \\
\hline Talent selection & $100 \%$ \\
\hline Talent development & $100 \%$ \\
\hline Talent retention & $100 \%$ \\
\hline
\end{tabular}

Table 2

Source: field survey, 2020

From the above table, all talent management processes types are being practiced by the organization.

\begin{tabular}{|c|c|c|c|}
\hline $\mathbf{S} / \mathbf{N}$ & Question & Mean & Std Deviation \\
\hline 1 & $\begin{array}{c}\text { The attraction of right skills and knowledge has improved your } \\
\text { firms' sales, image and overall performance }\end{array}$ & 4.2 & 1.10 \\
\hline 2 & $\begin{array}{c}\text { Talent acquisition promotes quality of life in the organization and } \\
\text { society }\end{array}$ & 4.05 & 1.05 \\
\hline 3 & Talent acquisition is a source of competitive advantage & 3.8 & 1.38 \\
\hline 4 & $\begin{array}{c}\text { The specification of core competencies prior to the hiring } \\
\text { procedure is essential in attracting the right people in the } \\
\text { organization }\end{array}$ & 4.3 & 0.80 \\
\hline 5 & $\begin{array}{c}\text { The acquisition /attraction of talents in the organization has } \\
\text { helped in identifying best ways of delivering value to the } \\
\text { customer/society in terms of quality and fair price. }\end{array}$ & 3.75 & 1.25 \\
\hline 6 & $\begin{array}{c}\text { The ability of your firm to produce environment free car is } \\
\text { attributed to the pool of experienced talents present in the } \\
\text { organization. }\end{array}$ & 4.25 & 1.11 \\
\hline
\end{tabular}




\begin{tabular}{|c|c|c|c|}
\hline $\mathbf{S} / \mathbf{N}$ & Question & Mean & Std Deviation \\
\hline 7 & $\begin{array}{l}\text { The development of through talent development through training } \\
\text { has helped the firm in complying with regulatory and } \\
\text { environmental demands. }\end{array}$ & 3.95 & 1.19 \\
\hline 8 & $\begin{array}{l}\text { Talent development has helped the firm in creating the needed } \\
\text { goods the society wants thereby raising their standard of living. }\end{array}$ & 4.1 & 1.11 \\
\hline 9 & $\begin{array}{l}\text { The development of talent has helped the company in innovating } \\
\text { products that are environmentally friendly. }\end{array}$ & 3.3 & 1.38 \\
\hline 10 & Your company ensures that product is recycled and re-used. & 4.35 & 0.87 \\
\hline 11 & $\begin{array}{l}\text { Wastes are sold to recyclers instead of dumping them in the } \\
\text { landfills. }\end{array}$ & 3.8 & 1.36 \\
\hline 12 & Products are labeled according to the requirement of the law. & 4.3 & 0.80 \\
\hline 13 & $\begin{array}{l}\text { Talent development has helped employees' in acquiring needed } \\
\text { skills which has improved organizational performance over the } \\
\text { years. }\end{array}$ & 3.75 & 1.25 \\
\hline 14 & $\begin{array}{l}\text { The sustained competitive advantage of the firm can be linked to } \\
\text { the effective utilization of skills and knowledge. }\end{array}$ & 4.25 & 1.11 \\
\hline
\end{tabular}

Table 3: An Assessment of the Relationship between Talent Management (TM) Practice and

Entrepreneurial Sustainability $(N=20)$

Source: Statistical Computations 2020

\subsection{Testing of Hypotheses}

- Ho: There is no significant effect between talent attraction and entrepreneurial sustainability.

- $\mathrm{Ho}_{2}$ : Talent development has no significant effect on entrepreneurial sustainability.

- $\mathrm{Ho}_{3}$ : Talent attraction has no significant effect on green product development.

- $\mathrm{Ho}_{4}$ : Talent development has no significant effect on profit of an organization.

The hypotheses formulated for this study was tested using T-statistics. The values of the mean item scores in table 4 above were used as the data for the statistical computations with the result shown in the table 4 and 5, 6, and 7 .

\begin{tabular}{|c|c|c|c|c|c|c|c|c|}
\hline Mean & $\begin{array}{c}\text { Standard } \\
\text { deviation }\end{array}$ & $\begin{array}{c}\text { Standard } \\
\text { error }\end{array}$ & $\mathbf{N}$ & $\mathbf{D F}$ & Alpha (significance level) & $\begin{array}{c}\text { P } \\
\text { value }\end{array}$ & Tcal & $\begin{array}{c}\text { Ttab } \\
\mathbf{0 . 0 5 , 3}\end{array}$ \\
\hline 4.0875 & .519 & .107 & 4 & 3 & $5 \%$ & .000 & 37.245 & 2.353 \\
\hline
\end{tabular}

Table 4: T-Test Statistical Computation Result on Talent Attraction and

Entrepreneurial Sustainability

SPSS Output (2020)

The above was tested with question $1,2,3$, and 4 respectively

With 3 degree of freedom (DF) and $5 \%$ level of significance, the T-test calculated $\left(\mathrm{T}_{\text {cal }}=37.245\right)$ is greater than $\mathrm{T}$-test tabulated ( $\mathrm{T}_{\text {tab }} 0.05,3=2.353$ ) as such, the alternative hypothesis was accepted; which states that "there is significant effect between talent attraction and entrepreneurial sustainability'.

\begin{tabular}{|c|c|c|c|c|c|c|c|c|}
\hline Mean & $\begin{array}{c}\text { Standard } \\
\text { Deviation }\end{array}$ & $\begin{array}{c}\text { Standard } \\
\text { Error }\end{array}$ & $\mathbf{N}$ & $\mathbf{D F}$ & $\begin{array}{c}\text { Alpha } \\
\text { (Significance } \\
\text { Level) }\end{array}$ & P-value & Tcal & $\begin{array}{c}\text { Ttab } \\
\mathbf{0 . 0 5 , 3}\end{array}$ \\
\hline 3.900 & .486 & .197 & 5 & 4 & $5 \%$ & .000 & 21.528 & 2.132 \\
\hline
\end{tabular}

Table 5: T-Test Statistical Computation Result on Talent Development and Entrepreneurial Sustainability SPSS Output (2020)

With degrees of freedom (DF) and 5\% level of significance, the T-test calculated $\left(\mathrm{T}_{\text {cal }}=21.528\right)$ is greater than $\mathrm{T}$ test tabulated ( $\mathrm{T}_{\text {tab }} 0.05,4=2.132$ ) as such, the alternative hypothesis was accepted; which states that talent development has significant effects on entrepreneurial sustainability.

\begin{tabular}{|c|c|c|c|c|c|c|c|c|}
\hline Mean & $\begin{array}{c}\text { Standard } \\
\text { Deviation }\end{array}$ & $\begin{array}{c}\text { Standard } \\
\text { Error }\end{array}$ & N & DF & $\begin{array}{c}\text { Alpha } \\
\text { (Significance Level) }\end{array}$ & $\begin{array}{c}\text { P } \\
\text { value }\end{array}$ & $\begin{array}{c}\text { Tcal } \\
\text { Ttab } \\
\mathbf{0 . 0 5 , 3}\end{array}$ \\
\hline 4.025 & .531 & .197 & 5 & 4 & $5 \%$ & .000 & 21.528 & 2.353 \\
\hline
\end{tabular}

Table 6: T-Test Statistical Computation Result on Talent Attraction and

Green Product Development

SPSS Output (2020)

With 4 degree of freedom (DF) and 5\% level of significance, the T-test calculated $\left(\mathrm{T}_{\mathrm{cal}}=21.528\right)$ is greater than $\mathrm{T}$ test tabulated ( $\mathrm{T}_{\mathrm{tab}} 0.05,4=2.353$ ) as such, the alternative hypothesis was accepted; which states that "talent development has significant effect on green product development 


\begin{tabular}{|c|c|c|c|c|c|c|c|c|}
\hline Mean & $\begin{array}{c}\text { Standard } \\
\text { Deviation }\end{array}$ & $\begin{array}{c}\text { Standard } \\
\text { Error }\end{array}$ & N & DF & $\begin{array}{c}\text { Alpha } \\
\text { (Significance Level) }\end{array}$ & $\begin{array}{c}\text { P } \\
\text { Value }\end{array}$ & $\begin{array}{c}\text { Tcal } \\
\text { Ttab } \\
\mathbf{0 . 0 5 , 3}\end{array}$ \\
\hline 4.062 & .521 & .197 & 4 & 3 & $5 \%$ & .000 & 21.528 & 2.353 \\
\hline
\end{tabular}

With 4 degree of freedom (DF) and 5\% level of significance, the T-test calculated $\left(\mathrm{T}_{\text {cal }}=21.528\right)$ is greater than $\mathrm{T}$ test tabulated $\left(\mathrm{T}_{\mathrm{tab}} 0.05,3=2.353\right)$ as such, the alternative hypothesis was accepted; which states that "Talent development has significant effect on profit of an organization'.

The above findings are supported by the study of Jokar (2012) whose investigation is on analysis of the relationship between talent management and performance evaluation of Elite employees. Their findings indicate the existence of relationship between talent management and performance evaluation. Also, our finding is supported by the study of Mosavi (2010) on designing and explaining factors of organizational entrepreneurial promoters with dimensions of organizational entrepreneurial trends in the Physical Education Organization of the Islamic Republic of Iran. The study's findings show a positive and significant relationship between the factors of organizational environmental trends.

\section{Conclusion}

It has been forecasted, that in the face of environmental turbulence globalization, demographic changes, the increasing role of technology, intellectualization of work, the importance of talent management issues will continue to grow. Business growth, the key to entrepreneurial sustainability and economic development necessarily assumes the effective use of resources including human resources to create and exploit new opportunities. Talent management is seen as organizational activities aimed at attracting, selecting, developing and retaining the best employees with the most strategic roles (those roles are necessary to achieve organizational strategic priorities). Talent identification, succession planning, talent development, and talent retention are management process identified in the study.

In can be concluded Innoson Motors Ltd has a culture of attracting and developing talent and has seen these human resources function as a source of competitive advantage. It can further be concluded that Innoson Motors Ltd profit has improved significantly as a result of talented pool of employees it was able to attract and develop. The results further show that the attraction and development of talents have helped the firm producing green products that are of environmental standard. Conclusively, for an organization to balance its economic health (profit), social equity (people) and environmental resilience (plannet) and remain competitive, talent management becomes sacrosanct.

\section{Recommendations}

- For firms to succeed in selecting the right talents, organizations should present a credible and attractive disposition that will make it attractive to external stakeholders.

- It is recommended that management should identify and effectively manage available talent to ensure entrepreneurial sustainability.

- To achieve entrepreneurial sustainability, management should give sense of belonging to its employees to elicit maximum cooperation from them.

- Firms should continue to invest in the development of pools of talents available in the organization for sustained competitiveness.

\section{References}

i. Abdi, R. (2011) The Impact of talent Management in the Production process in Iran Khodro Company'

ii. Master's Thesis, Payam Noor University, Faculty of Humanities, Department of Management.

iii. AlAriss, A., Cascio, W. F., and Paauwe, J. (2014) Talent management: current theories and future research directons. Journal of World Business, 49 (2): 173 - 179.

iv. Alugbuo, C. C. (2004) Elements of Management Owerri: Stanley George Publications.

v. Barabudi, M. (2011), "Investigating the relationship between Talent Management and Organizational commitment in the social security organization of Golestan Province 'Master's Thesis Payam

vi. Noor University, Faculty of Management and Accounting Tehran.

vii. Barney, J. B. (1991) Firm's resources and sustained Competitive Advantage. Journal of Management, 17, 99-120.

viii. Bethel-Langenegger, P., Mahler, P. and stafelbach, B. (2011) Effectiveness of talent management strategies, European J. International Management 5 (5):524 -539.

ix. Dean, T. J. and McMullen, J.S., (2007). Toward a theory of sustainable entrepreneurial reducing environmental degradation through entrepreneurial action. Journal of business venturing, 22(1).

x. P. 50-76.

xi. Ebrahim, A., Battilana, J. and Mair, J., (2014). The governance of social enterprises: Mission drift and accountability challenges in hybrid organizations. Research in organizational behavior, 34, pp. 81-100.

xii. Eroglu, O., and Picak, M. (2011). Entrepreneurship, National Culture and Turkey. International Journal of Business and Social Science, 2(16), 146-151.

xiii. Glen, C. (2007) Fostering talent opportunity: getting past first base, strategic Direction. 23(10) pp. 3-5.

xiv. DOI:10.1108/02580540710824220. 
xv. Harris, J. G., Graig, E. and Light, D. A., (2011). Talent and analytics: New Approaches, Higher ROI, Journal of Business strategy 32(6):4-13.

xvi. Heinen, J., and Neill, C. (2004) Managing talent to maximize Performance. Employment relations Today Summer, 3192), pp. 67-82.

xvii. Hockerts, K. and Wistenhagen, R., (2010). Greening Goliaths versus emerging Davids Theorizing about the role of incumbents and new entrants in sustainable entrepreneurship. Journal of Business Venturing, 25(5), pp. 481492.

xviii. Joker, D. (2012). “Analyzing the Relationship between Talent Management and Performance Evaluation of Elite Employees by Using Data Employment analysis technique in the National

xix. Iranian Oil Pds Distribution', Master's Thesis, University of Allameh Tabatabaei, Faculty of management and accounting

xx. Keoye. k. N. (2014). Examining the effect of talent management on organizational performance M.Sc.

xxi. Thesis in business administration (human resource management), Kenyatta University.

xxii. Lyightin, N. O. (2015). What could entrepreneurship do for sustainable development? A corporate social responsibility-based approach. Procedi-social and behavioral Sciences, 195, pp. 1226-1231.

xxiii. Madam, A. O. and Bhatnagar J. (2018) Talent management in New Ventures. Indian Institute of Technology Delhi, India.

xxiv. Mariann, V. and Kristin T. (2014), Talent Management: "What is the value of Talent Management in Business Organizations?' Master Thesis M.Soc. Sc. In Service Management (SEM), Copenhagen Business School.

xxv. McMullen, D. A., Sanchez, M. H., and Stout, D. E. (2011). Initial Pubic Offering and the Role of the

xxvi. Management accountant. Management accounting quarterly, 12(2), 11-24.

xxvii. Micheals, E. Handfield-Jones. H, and Axelrod. B. (2001) The war for Talent. Boston: Harvard Business School Publishing.

xxviii. Mosavi, R. and Seyedeh T. (2010), "Designing and Explaining the Factors of organizational entrepreneurial promoters by dimensions of organizational entrepreneurial trends in the Physical education organization of the Islamic Republic of Iran', Ph.D. Thesis, University of Payam Noor of Tehran province, faculty of humanifies and physical education.

xxix. Ndubuisi, N. O. (2012). Relationship between entrepreneurship, innovation and performance:

хxx. Comparing small and medium-size enterprises. Journal of Research in Marketing and Entrepreneurship, 14(2), 214 -236. doi:10.1108/14715201211271429.

xxxi. Nicholls-Nixon, C. L., Cooper, A. C. and Woo, C. Y., (2000). Strategic Experimentation: Understanding change and performance in new ventures. Journal of Business Venturing, 15(5), pp. 493-521.

xxxii. Pacheco, D. F., Dean, T. J., and Payne, D. S. (2010). Escaping the green prison: Entrepreneurship and the creation of opportunities for sustainable development Journal of Business Venturing, 25(5), pp. 461-480.

xxxiii. Sani S. and Hassan, M. M. (2016). Investigating the Impact of Talent Management on Organizational

xxxiv. Entrepreneurship of the employees of state welfare organization. International Journal of Humanities and Cultural Studies ISSN 2356-5926.

xxxv. Shepherd, D. A. and Patzelt, H. (2011). The new field of sustainable entrepreneurship: studying entrepreneurial action linking "what is to be sustained' with "what is to be developed'.

xxxvi. Entrepreneurship Theory and practice, 35(1), pp. 137-163.

xxxvii. Smell, S. A., Youndf, M. A., and Wright P.M. (1996) Establishing a framework of research in strategic human resource management: merging resource theory and organizational learning. in $\mathrm{G}$. R.

xxxviii. Ferrics (Ed), Research in personnel and human resources management (pp 61-90).

xxxix. Sweetland S. R. (1996) Human Capital Theory: foundation of a field of Inquiry Review of Educational Research 66: pp. 341-359. 